\title{
Coworkers' and Supervisor Interactional Justice: Correlates of Extension Personnel's Job Satisfaction, Distress, and Aggressive Behavior
}

\author{
Olugbenga J. Ladebo \\ Joseph M. Awotunde \\ Petra AbdulSalaam-Saghir \\ University of Agriculture, Abeokuta, Nigeria.
}

\begin{abstract}
This paper examined the effects of coworkers and supervisor interactional fairness on employees' job satisfaction, distress, and aggressive behavior. Surveys were employed to elicit data from 270 extension personnel from two Agricultural Development Programs in Nigeria. Hierarchical regression analyses indicated that fairness from both supervisors and coworkers were negatively related to job distress and aggressive behaviors and employees would respond with dissatisfaction to unfair treatments from their supervisors. The implications of findings are discussed.
\end{abstract}

\section{Introduction}

The literature on employee-employer relations shows that an employee expects the organization to treat him/her with respect, dignity, honesty and to extend equal treatment to all members (Janssens, Sels, \& Van den Brande, 2003; Kickul \& LiaoTroth, 2003). Bies and Moag (1986) referred to this notion as interactional justice, which is the perception of the quality of treatment an employee receives when policies and procedures are implemented in the workplace.

The assessment of organizational practices and behavior of authority figures in terms of fairness does not usually depend on how fairly the employee was actually treated, but rather on how fairly the employee perceives that s/he was treated (Greenberg, 1990). Perceptions of interactional justice play a role in the determination of employees' work attitudes and behavior (Cohen-Charash \& Spector, 2001; Colquitt, Conlon, Wesson, Porter, \& Yee $\mathrm{Ng}, 2001)$.

Researchers have suggested that organizations should focus not only on formal procedures and outcomes, but also on perceived unfair treatment by managers and coworkers (Barling \& Phillips, 1993; Coyle-Shapiro, Kessler, \& Purcell, 2004). Most research efforts on interactional justice assumed that the construct was unidimensional without specifying the sources of the unfair treatments, or that the supervisors were assumed to solely be responsible for the unfairness in the workplace (e.g. Colquitt, 2001; Murphy et al., 2003).

Thus, unfair treatment at work has been largely measured without distinguishing between supervisor and coworker unfair treatment. This notion is contrary to studies on 
social exchange relationships, which indicates that an employee is always in regular exchange relations with the supervisor and coworkers (Brandes, Dharwadkar, \& Wheatley, 2004; Vandenberghe, Bentein, \& Stinglhamber, 2004).

This paper therefore examined the effects of unfairness by the supervisors and coworkers on employees' attitudinal and behavioral outcomes among agricultural extension workers. The choice of sample was premised on the need for additional data on unfair treatments from employees in different industries and organizations especially, from a developing nation such as Nigeria (Donovan, Drasgow, \& Munson, 1998).

\section{Conceptual Analysis and Hypotheses}

\section{$\underline{\text { Interactional Justice }}$}

Interactional justice concerns the individual's perception of the quality of treatment experienced when organizational procedures are implemented (Bies \& Moag, 1986). Empirical evidence suggests that employees show much concern for the treatment they receive from authority figure and the adequacy with which formal decision making procedures are explained (Bies, Shapiro, \& Cummings, 1988). Perceptions of interactional justice are important over time and are unaffected by the individual's selfinterest.

The explanation for interactional justice in the workplace is grounded in social exchange theory and norm of reciprocity (Cropanzano \& Mitchell, 2005). From the social exchange perspective, employees expect fair, honest, courteous, and truthful treatments from the organization and/or its agents. Based on the norm of reciprocity, employees who perceive fair treatments by authorities are more likely to evidence positive actions through greater commitments to the values and goals of the organizations; exhibit increased job satisfaction, organizational citizenship behaviors, improved job performances and reduced withdrawal behaviors (Cohen-Charash \& Spector, 2001; Colquitt et al., 2001).

Research on psychological contract indicated that employees expect their employers to provide pleasant work environment that supports harmonious working relationships (Kickul \& Liao-Troth, 2003). Because of the importance of good quality social exchange relationships in workplaces, organizations strive to encourage supervisors and employees to willingly interact with each other. However, regular supervisor-subordinate social exchange relations are important in influencing desirable individual and organizational outcomes (see Becker et al., 1996; Raabe \& Beehr, 2003; Zdaniuk \& Levine, 2001).

Further support for the argument that an employee maintains a separate relationship with coworkers and supervisor could be found from person-group fit (PG fit) (KristofBrown, Jansen, \& Colbert, 2002). The PG fit suggests that though coworkers are a distinct part of the work environment, an employee is expected to work harmoniously 
with other members (i.e. achieve a person-group fit), which has positive implications for an individual's work satisfaction (Kristof-Brown et al., 2002).

Literature on facets of job satisfaction suggests that employees are able to distinguish between the quality of relationships with coworkers and supervisors on one hand (Raabe \& Beehr, 2003); supervisors' behaviors in terms of implementing fair evaluation procedure and delegating tasks have direct impact on subordinates' perceptions of trust in supervisor and organizational commitment (Duffy \& Ferrier, 2003).

Regarding coworkers, studies show that coworkers provide social support to each other (Self, Holt, \& Schaninger, 2005). Conversely, supervisors and coworkers can constitute sources of interpersonal conflicts for an employee in the workplace with the implication for acts of wide ranging antisocial behaviors (Bruk-Lee \& Spector, 2006). Therefore, unfair treatment received from coworkers and the supervisors are of considerable concerns to employees (Donovan et al., 1998). This paper proposed that employees' are able to distinguish between a coworker and supervisor's unfair treatments.

Hypothesis 1: Sources of perceived interactional fairness are the supervisors and coworkers.

\section{$\underline{\text { Job Distress }}$}

Workplace stress has been identified as often contributing to the wellbeing of employees and organizations. Therefore, it becomes imperative to understand the causes of workplace stress and employees' reactions to it. Vigoda (2002) suggests that job distress is experienced when an individual reacts to work-related environmental stressors. Empirical evidence indicates that a low to moderate amount of stress that provides positive reinforcement can benefit the employee and the organization (Boswell, Olson-Buchanan, \& LePine., 2004; Cavanaugh, Boswell, Roehling, \& Boudreau, 2000; Tuten \& Neidermeyer, 2004). However, severe and chronic exposure to stressful conditions eventually wear down the employee, leading to job dissatisfaction, (Poon, 2003) anxiety, tension, anger and depression (Greenglass, Burke, \& Moore, 2003) as well as aggressive behaviour (Vigoda, 2002).

Studies on social relations in the workplace indicate that poor quality exchange relations among members may predispose individuals to stress reactions. Social stressors may include unfair behavior, social animosities, conflicts with coworkers and supervisors and a negative workplace climate (see Dorman \& Zapf, 2002; Bruk-Lee \& Spector, 2006).

The emotion-centred model of voluntary behaviour provides the theoretical explanation for the social stressors-strain linkage (Spector \& Fox, 2002). Based on the emotioncentered model, perceived unfairness from the supervisor and coworkers could be appraised as negative environmental stimuli that will elicit negative emotions. The negative emotions are not necessarily target specific, but are capable of inducing an employee stress reactions like job dissatisfaction, distress, and aggressive acts. Research evidence shows that unfair treatment at work is positively associated with 
psychological strain (Francis, 2005). An employee may develop stress reactions due to membership of a less cohesive workgroup, having inadequate social support from coworkers, or exposure to hostile acts from coworkers (Bruk-Lee \& Spector, 2006; Etzion, 1984; Mueller, De Coster, \& Estes, 2001).

The leadership literature indicates that most employees considered relations with supervisors as most stressful (Tepper, 2007). This is because supervisors create stress by ignoring employee ideas and concerns, withholding information from them and failing to clarify roles and responsibilities (Reece \& Brandt, 1999). Therefore, the following hypotheses are proposed:

Hypothesis 2a: Perceptions of coworkers' fairness are significantly negatively related to job distress.

Hypothesis 2b: Perceptions of supervisor's fairness are significantly negatively related to job distress.

\section{$\underline{\text { Job Satisfaction }}$}

Job satisfaction as an indication of employee wellbeing refers to an affective feeling emanating from the perception of an individual that his/her current job allows for fulfillment of important job values (Noe et al., 1994). Job satisfaction in this context reflects an employee's perception rather than reality about certain aspects of the job, relative to his/her values. And so employees' dissatisfaction could be associated with less organizational commitment, higher stress, lateness or absenteeism from work, fewer citizenship behaviors, low productivity or exit from the organization (Chiu \& Kosinski, 1997; Ladebo, 2004; Noe et al., 1994).

Literature is replete with models that are employed to explain employees' job satisfaction. However, research indicates that a stressed worker may develop negative affective feelings to his/her job (Cavanaugh et al., 2000; Chiu \& Kosinski, 1997; Poon, 2003). For instance, a worker, who experiences constant abuse from the supervisor or is unable to cope with the perceived political climate of the workplace, may develop stress reactions (Vigoda, 2002).

The absence of a viable alternative in the job market and the family's financial need could constrain the worker to remain but apparently dissatisfied with the job. Therefore, it is proposed that job distress is negatively related to job satisfaction.

\section{Hypothesis 3a: Job distress is negatively related to job satisfaction.}

A framework that is employed to explain employees' satisfaction is interactional justice in the workplace. When the expectation of an employee is met, $\mathrm{s} / \mathrm{he}$ is more likely to reciprocate the fair treatment received from the coworkers and supervisors by developing a positive affective feeling towards his/her job. Studies that employed the unidimensional concept of interactional justice indicated that employee satisfaction is 
enhanced when there is interactional fairness in the workplace (Cohen-Charash \& Spector, 2001; Colquitt et al., 2001; Colquitt, 2001).

It is, therefore, suggested that fair treatments received from the supervisors and coworkers should provide the strong reason for an employee to feel satisfied with his/her job. Available literature supports the links between job satisfaction and fair treatment received from the supervisor and coworkers (Donovan et al., 1998).

This leads to postulation of the following hypotheses:

Hypothesis 3b: Perceived coworkers' fairness is positively related to job satisfaction.

Hypothesis 3c: Perceived supervisor fairness is positively related to job satisfaction.

\section{Aggressive Behavior}

Workplace aggressive behavior refers to efforts by an employee to harm coworkers or the organization in which s/he is employed (Neuman \& Baron, 1997). Specific acts of workplace aggressive behavior may be verbal (yelling, shouting, criticizing, or cursing), or physical assault (punching or pushing). The behavior may involve a single act rather than repeated acts in the workplace.

An employee may aggress against a coworker, a supervisor against a subordinate or vice versa, and both sexes have been reported to engage in aggressive acts. Scholars are of the view that workplace aggression is rapidly becoming a workplace malady and no profession seems immune from it (Aitkinson, 2000; LeBlanc \& Kelloway, 2002; Namie, 2003).

Workplace aggression is believed to impact heavily on members in terms of diminished job satisfaction and self-confidence, disruption of career and burnout (Salin, 2003; Vartia, 2001; Wahl, 2002). The effects are also noticed on the organization's wellbeing in terms of turnover, increased lawsuits, liability claims by victims and reduced productivity (Aitkinson, 2000; LeBlanc \& Kelloway, 200; Namie, 2003; Salin, 2003).

Recent research efforts have focused on linking unfair treatment in the workplace to aggressive behavior. Theoretical explanation for the unfairness-aggressive behavior relations could be rooted in the emotion-centered model (Spector \& Fox, 2002). The emotion-centered model suggests that employees perceive and appraise social interactions that have behavioral implications in the workplace.

Perceptions of unfair treatment could be viewed as threats to wellbeing that in turn triggers negative emotions such as anger. Anger refers to an unpleasant emotion characterized by subjective feelings that vary in intensity from mild irritation or annoyance to intense fury or rage, which is a precursor to aggressive behavior (Smith, Glazer, Ruiz, \& Gallo, 2004). 
An employee suffering from negative emotions can easily be induced to aggress on members in the workplace. Scholars have argued that perceived unfairness from a supervisor and coworker may erode an employee's self-esteem or cause a feeling of personal deprivation that may culminate in aggressive reactions (Fortado, 2001; Neuman, 2000).

Empirical evidence demonstrates that perceived interactional injustice provides the motivation for employees to support (or perhaps engage in) aggression as a form of redressing unfairness in the workplace (Kennedy, Homant, \& Homant, 2004). Further support for the unfairness-aggressive behavior linkage could be found in the literature on workplace interpersonal conflict. An employee who is involved in interpersonal conflict with coworkers and supervisor is likely to engage in harmful behaviors directed at other employees and the organization (Bruk-Lee \& Spector, 2006). Thus, the following hypotheses are stated:

Hypothesis 4a: Perceived coworkers' fairness is negatively related to aggressive behavior.

Hypothesis 4b: Perceived supervisor fairness is negatively related to aggressive behavior.

Extant studies on stress show that an individual who feels stressed by the social climate of workplace overtime may develop aggressive behavior. The frustration arising from elevated stress may trigger negative emotion of anger, thereby reducing an employee's aggression threshold and consequently leading to the enactment of aggressive behavior.

Research evidence indicates that employees' responses to stress may include engaging in acts of sabotage, frequent complaints, and aggressive behavior (Chen \& Spector, 1992; Vigoda, 2002). Following this logic, it is proposed that an elevated job distress may predispose an employee to engage in aggressive behavior.

Hypothesis 4c: Job distress is positively related to aggressive behavior.

\section{Context of the Study}

Data were collected from a convenience sample of two Agricultural Development Programs in Southwest Nigeria. Agricultural extension syste $m$ in Nigeria is dominated by the World Bank initiated ADPs in each of the 36 states and the Federal Capital Territory. The extension personnel are required to disseminate production information to the farmers as well as train resource-poor farmers, who are the nation's main producers of agricultural products.

The withdrawal of World Bank support to the ADPs in the mid 1990s exposed the financial vulnerability of the ADPs, as the states were unable to provide adequate financial support to them. Thus, the continued viability of the ADPs has been of concern 
to all stakeholders in the extension system thereby prompting studies on willingness of farmers to pay for extension services (Apantaku, Sodiya, Apantaku, \& Fakoya, 2000; Chukwuone \& Agwu, 2005).

In response to inadequate government subventions, the ADPs have had to reduce the scope of their operations. In 2001, one of the sampled ADPs downsized and anecdotal evidence suggests that extension personnel engage in politicking to achieve personal goals and aspirations. The downsizing exercise translates into fewer extension personnel to cover existing farming population with the consequent negative implications for achieving effective extension coverage of farm families.

Though salaries are regularly paid, the payment of allowances is irregular or sometimes not paid at all, so the extension organizations find it difficult to maintain their equipment or acquire new ones. Extension personnel lack clear information on their role responsibilities and performance expectations. These have resulted in diminished morale of the extension workforce, caused inefficiency and reduced performance (Omotayo, Chikwendu, \& Adebayo, 2001). Anecdotal evidence suggests that dissatisfied personnel voluntarily exit extension organizations across the nation to take up more secure jobs.

With the high personnel turnover, most extension organizations still had to embargo recruitment of new staff to occupy the vacant positions. The uncertainty in the ADPs environment thus created a unique context for studying stress responses and aggressive behaviors of extension personnel.

\section{Method}

\section{Sample}

Two samples of extension personnel were surveyed in this study. Questionnaires were administered on 147 personnel in the first ADP and 126 or $85.7 \%$ responses were obtained. At the second ADP, 162 personnel were surveyed and 153 or $94.4 \%$ completed the questionnaires. Overall 309 extension personnel who were physically present at study sites were sampled anonymously and 279 respondents (i.e. $90.3 \%$ responses) voluntarily completed and returned the filled polling instruments to the authors. Nine questionnaires that were found to contain excessive missing data were excluded from further analysis. These reduced the sample size to 270 . The demographic profile of respondents was as follows: $79.3 \%$ were males with mean age of $38.27(S D=5.65)$ years and the average tenure on the job was $9.02(S D=5.25)$ years.

\section{$\underline{\text { Measures }}$}

Interactional fairness scale: Six items were selected from the original 18-item scale of Donovan et al. (1998) to assess coworkers' fairness (CF) and supervisors' fairness (SF). The decision to select six items from the original scale was because only the 
selected items seem to actually measure the focal constructs as articulated by Bies and Moag's (1986) rule of fairness of interactional treatment. Sample items from the SF's subscale are: Employees are treated like children in this organization, and Employees are treated with respect by their supervisors. The internal consistency reliability for the subscale was (Cronbach $\alpha=.68$ ). A sample item from the CF's subscale is: Coworkers treat each other with respect in this organization (Cronbach $\alpha=.70)$.

Aggressive behavior was assessed using a four-item scale (Vigoda, 2002). Sample items are: Lately, I have been personally involved in verbal confrontations with other extension personnel in my organization, and I think that sometimes my behavior toward other extension personnel can be regarded as aggressive (Cronbach $\alpha=.90)$. Job distress was measured using a six-item scale adapted from Vigoda (2002). Sample items are: I seem to tire quickly, and I work under a great deal of tension (Cronbach $\alpha=$ $.82)$.

Job satisfaction: Respondents' overall job satisfaction was captured using a five-item scale adapted from Brayfield and Rothe (1951). Sample items are: I find real enjoyment in my job, and I like my job better than the average person does (Cronbach $\alpha=0.75$ ). All scale items was anchored on a five-point Likert format of strongly disagreed (1) to strongly agreed (5). Scale scores were computed by summing across responses to items in a scale.

Control Variables: Information was collected on extension personnel's age and tenure in organization (measured in years), and gender (male $=1$ and female $=2$ ). Prior research has shown that age, sex, and tenure could covary with the predictors and criterions (Cohen-Charash \& Spector, 2001; Inness et al., 2005; Yoon \& Thye, 2002). Therefore, to control for their potential effects, the biographics were entered in the analyses.

\section{$\underline{\text { Statistical Analysis }}$}

A hierarchical regression procedure was employed to examine the effects of predictors on criterions. The hierarchical regression procedure allows for testing the variance contribution of main effects beyond that earlier explained by the control variables (Aiken \& West, 1991).

\section{Results}

\section{$\underline{\text { Tests of Hypotheses }}$}

An exploratory principal component (PC) analysis (Varimax rotation) was performed to test Hypothesis 1, to distinguish between the dimensions of coworkers' and supervisor's fairness. Table 1 indicates two distinct factors containing three items each that tapped the dimensions of coworkers' and supervisor's fairness. Item loadings of \pm .70 and above were included on a factor and the two-factor solution explained $63.09 \%$ variance in scores. This exploratory factor analysis supports the distinction between coworkers' and supervisor's fairness. 
Table 1

Results of Principal Component Analysis (Varimax Rotation) of Interactional Fairness Scale

\begin{tabular}{lll}
\hline Item & $\mathrm{FI}$ & $\mathrm{FIl}$ \\
\hline 1. Employees are treated like children in this organization! & .84 & .14 \\
2. Employees are treated with respect in this organization & .74 & .20 \\
3. Supervisors yell at employees in this organization! & .72 & .02 \\
4. Coworkers often argue with each other in this & .14 & .85 \\
organization! & & \\
5. Coworkers often treat each other with respect in this & -.02 & .76 \\
organization & & \\
6. Coworkers often put each other down in this organization! & .37 & .71 \\
Eigenvalue & 1.92 & 1.87 \\
Percent variation (\%) & 32.01 & 31.08 \\
Alpha & .68 & .70 \\
\hline
\end{tabular}

Note: Factor labels: $\mathrm{F} \mathrm{I}=$ Supervisors' fairness; F II = Coworkers' fairness;

$!=$ Negatively worded statements were reverse scored. $\mathrm{N}=270$.

However, in Table 2 are the descriptive statistics, alpha reliabilities, and correlations of study variables. The internal consistency reliabilities of the scales employed for the study ranged from .68 to .90 and are considered good (Hair, Anderson, Tatham, \& Black, 1992). Table 3 shows that the controls of: age, sex and tenure were unrelated to job distress on Step I. On step II, the hypothesized negative relationships between job distress and $\mathrm{CF}$ and $\mathrm{SF}(\mathrm{H} 2 \mathrm{a}$ and $\mathrm{H} 2 \mathrm{~b})$ were supported. Job distress was negatively related to CF $(\beta=-.27, p<.0001)$ and SF $(\beta=-.28, p<.0001)$. The variance explained by both sources of fairness on entry in the equation was 20 per cent $\left(\Delta R^{2}, p<.0001\right)$. The result implies that perceived unfair treatment from coworkers and supervisor could lead to job distress.

Table 2

Descriptive Statistics, Reliabilities, and Bivariate Correlations among Study Variables

\begin{tabular}{|c|c|c|c|c|c|c|c|c|}
\hline Variables & 1 & 2 & 3 & 4 & 5 & 6 & 7 & 8 \\
\hline 1. Age & - & & & & & & & \\
\hline 2. Sex & $-.25^{\star * *}$ & - & & & & & & \\
\hline 3. Tenure & $.71^{\star \star \star}$ & $-.20^{\star \star \star}$ & - & & & & & \\
\hline $\begin{array}{l}\text { 4. Job } \\
\text { satisfaction }\end{array}$ & .01 & .05 & -.11 & .75 & & & & \\
\hline $\begin{array}{l}\text { 5. Coworkers' } \\
\text { fairness }\end{array}$ & -.07 & -.09 & -.11 & $.27^{\star \star *}$ & .70 & & & \\
\hline $\begin{array}{l}\text { 6. Supervisor } \\
\text { fairness }\end{array}$ & -.08 & .04 & $-.17^{\star *}$ & $.53^{\star \star *}$ & $.34^{* * *}$ & .68 & & \\
\hline 7. Job distress & .02 & -.04 & .08 & $-.32^{\star \star \star}$ & $-.36^{\star * \star}$ & $-.38^{\star * \star}$ & .82 & \\
\hline $\begin{array}{l}\text { 8. Aggressive } \\
\text { behavior }\end{array}$ & $.18^{\star \star}$ & -.03 & $.20^{* \star *}$ & .07 & $-.17^{\star \star}$ & $-.16^{\star}$ & $.14^{*}$ & .90 \\
\hline Mean & 38.27 & - & 9.02 & 2.59 & 3.96 & 3.48 & 2.64 & 1.51 \\
\hline SD & 5.65 & - & 5.25 & 0.69 & 0.59 & 0.59 & 0.86 & 0.71 \\
\hline
\end{tabular}


Table 3

Results of Hierarchical Regression Analyses of Job Distress on Controls and Predictors

\begin{tabular}{ll}
\hline Variables & $\beta$ \\
\hline Step I: Controls & \\
1. Age & -.08 \\
2. Sex & -.04 \\
3. Tenure & .13 \\
$\left(\Delta R^{2}\right)$ & $(.011)$ \\
F-change & $(.95)$ \\
Step II: Predictors & \\
4. Coworkers' fairness (CF) & $-.27^{\star}$ \\
5. Supervisor fairness (SF) & $-.28^{*}$ \\
$\left(\Delta R^{2}\right)$ & $(.200)$ \\
$F-c h a n g e$ & $\left(33.45^{\star}\right)$ \\
Total $R^{2}$ (adj) & .196 \\
$R^{2}$ & .211 \\
$R$ & .459 \\
$F$ & $14.09^{\star}$ \\
$D f$ & $5 / 264$ \\
\hline${ }^{*} p<.0001 . \mathrm{N}=270$. &
\end{tabular}

In Table 4, the effects of the controls (age, sex, and tenure) on job satisfaction were controlled for on step I. On step II, the hypothesized negative relationship between job distress and satisfaction received support $(\mathrm{H} 3 \mathrm{a}),(\beta=-.30, p<.0001)$. Job distress explained significant 9 per cent variance $\left(\Delta R^{2}, p<.0001\right)$ in the criterion. Step III indicates that job satisfaction was related to $\operatorname{SF}(\beta=.45, p<.0001)$ and unrelated to $\mathrm{CF}$ $(\beta=.08 \mathrm{~ns})$. Both sources of fairness explained significant 18.8 per cent variance $\left(\Delta R^{2}\right.$, $p<.0001)$ in the criterion. Thus, the hypothesized positive relationships between job satisfaction and $\mathrm{CF}(\mathrm{H} 3 \mathrm{~b})$ and $\mathrm{SF}(\mathrm{H} 3 \mathrm{c})$ received mixed support. Perceived supervisor and not coworkers' fairness is likely to promote job satisfaction. 
Table 4

Results of Hierarchical Regression Analyses of Job Satisfaction on Controls and Predictors

\begin{tabular}{|c|c|}
\hline Variables & $\beta$ \\
\hline \multicolumn{2}{|l|}{ Step l: Controls } \\
\hline 1. Age & $.18^{*}$ \\
\hline 2. Sex & .04 \\
\hline 3. Tenure & $-.22^{* *}$ \\
\hline$\left(\Delta R^{2}\right)$ & $(.028)$ \\
\hline$F$-change & $(2.51)$ \\
\hline \multicolumn{2}{|l|}{ Step II: Predictors } \\
\hline $\begin{array}{l}\text { 4. Job distress } \\
\left(A R^{2}\right)\end{array}$ & $-.30^{* \star \star}$ \\
\hline $\begin{array}{l}\left(\Delta R^{2}\right) \\
F \text { - change }\end{array}$ & $(.090)$ \\
\hline \multicolumn{2}{|l|}{ Step III } \\
\hline 4. Coworkers' fairness (CF) & .08 \\
\hline 5. Supervisor fairness (SF) & $.45^{\star \star \star}$ \\
\hline$\left(\Delta R^{2}\right)$ & $(.188)$ \\
\hline F-change & $\left(35.58^{\star * *}\right)$ \\
\hline Total $R^{2}$ (adj) & 290 \\
\hline$R^{2}$ & .306 \\
\hline$R$ & .553 \\
\hline$F$ & $19.30^{* * *}$ \\
\hline$D f$ & $6 / 263$ \\
\hline
\end{tabular}

Results in Table 5 supported hypothesis $4 \mathrm{c}$ because job distress was positively related to aggressive behaviors $(\beta=.17, p<.01)$ after controlling for the effects of age, sex, and tenure on step I. Thus, a distressed employee is likely to exhibit aggressive behavior in the workplace. On step III, aggressive behavior was inversely related to CF $(\beta=-.13, p<.05)$ and SF $(\beta=-.19, p<.05)$. The explained variance by both sources of fairness in aggressive behavior was $\left(\Delta R^{2}=.04, p<.01\right)$. The perceived mistreatment by coworkers and supervisor are related to aggressive behavior and this supports $\mathrm{H} 4 \mathrm{a}$ and $\mathrm{H} 4 \mathrm{~b}$, respectively. 
Table 5

Results of Hierarchical Regression Analyses of Aggressive Behavior on Controls and Predictors

\begin{tabular}{|c|c|}
\hline \multirow{2}{*}{\multicolumn{2}{|c|}{$\begin{array}{l}\text { Variables } \\
\text { Step I: Controls }\end{array}$}} \\
\hline & \\
\hline 1. Age & .08 \\
\hline 2. Sex & .01 \\
\hline 3. Tenure & .14 \\
\hline$\left(\Delta R^{2}\right)$ & $(.041)$ \\
\hline F-change & $\left(3.81^{*}\right)$ \\
\hline \multicolumn{2}{|l|}{ Step II:Predictors } \\
\hline 4. Job distress (JD) & $.17^{\star \star}$ \\
\hline 5. Job satisfaction & $.14^{*}$ \\
\hline$\left(\Delta R^{2}\right)$ & $(.034)$ \\
\hline F-change & $\left(4.83^{\star \star}\right)$ \\
\hline \multicolumn{2}{|l|}{ Step III } \\
\hline 6. Coworkers' fairness (CF) & $-.13^{*}$ \\
\hline 7. Supervisor fairness (SF) & $-.19^{*}$ \\
\hline$\left(\Delta R^{2}\right)$ & $(.042)$ \\
\hline F-change & $\left(6.28^{\star \star}\right)$ \\
\hline Total $R^{2}$ (adj) & .094 \\
\hline$R^{2}$ & .117 \\
\hline$R$ & .343 \\
\hline$F$ & $3.98^{* * *}$ \\
\hline$D f$ & $7 / 262$ \\
\hline
\end{tabular}

\section{Discussion}

Previous research has shown that feelings of unfair treatment could provoke job distress, dissatisfaction and aggressive behaviors in employees. This paper sought to add to existing literature by demonstrating through an exploratory PC analysis that coworkers' and supervisor's fairness are distinct dimensions subsumed in interactional fairness in a sample of agricultural extension personnel. The results of an exploratory PC analysis were consistent with Hypothesis 1. This indicates that sources of perceived fairness are coworkers and supervisor, and employees are able to identify the source(s) of mistreatment in the workplace. This result is consistent with those of Donovan et al. (1998).

Supervisor and coworkers' fairness were negatively related to job distress as hypothesized in this study. This implies that perceived unfairness from coworkers and supervisors could lead to distress. Prior research has indicated that perceived unfairness in the workplace could result in distress (Francis, 2005). However, the negative relationships between job distress, supervisor and coworkers fairness attests 
to the emotion-centered prediction that strain results from perceived poor social relations on the job (Spector \& Fox, 2002). The strain resulting from perceived unfair treatment has implications for the employee(s) and organization's wellbeing.

The hierarchical regression results indicated that perceived SF, and not CF, is related to employees' satisfaction. The significant main effect of SF on satisfaction may be due to the proximality or saliency of the supervisor to an extension worker that is in consonance with extant literature. Employees are orientated to the more proximal relationship with supervisors and this has important implications for their work attitudes and behavior (see Becker et al., 1996; Raabe \& Beehr, 2003; Zdaniuk \& Levine, 2001). However, the lack of support for significant main effect of CF on satisfaction may be because of the periodic interaction among extension personnel. The reason is that they converge at the zonal offices from their work domains every fortnight to plan and to receive training on agricultural technologies they are to disseminate to farmers. The time interval between the meetings may serve to dissipate the negative emotions arising from any perceived unfairness by a coworker. Thus, the affective feelings to the job would remain unaffected.

Job distress was significantly related to satisfaction in this study and this is in agreement with extant literature. Thus, distressed employees are likely to feel dissatisfied (Chiu \& Kosinski, 1997; Poon, 2003; Vigoda, 2002). The stress literature indicates that sustained experience of stressful feelings could overtax the adaptive or coping responses of a worker, resulting in strain. The hypothesized positive relationship between job distress and aggressive behavior received support in this study and is in agreement with extant literature (Salin, 2003; Vigoda, 2002). A distressed employee would experience the somatic symptoms of strain and tension and would be less tolerant to coworkers or clients by exhibiting aggressive behavior (in terms of verbal or physical assault).

As stress is deleterious to employee relations in the workplace, managers might need to consider ways of keeping stress precipitating factors under tolerable levels in the workplace, since a minimal amount of stress is still beneficial to employees' attitudes and behavior (e.g. Boswell et al., 2004; Tuten \& Neidermeyer, 2004).

This study provides empirical evidence that perceived supervisor unfairness may influence an employee to engage in aggressive behavior, which is consistent with earlier literature. Studies that have examined effects of supervisory behaviors on individual employee's outcomes have come up with interesting findings. Zellars et al. (2002) reported that subordinates who worked with abusive supervisors performed less organizational citizenship behaviors than their nonabused counterparts. Further, subordinates of abusive supervisors had less trust in their supervisors and weaker organizational commitment (Duffy \& Ferrier, 2003).

The hypothesized negative relationship between coworkers' fairness and aggressive behavior was supported by the results. The results support past research on the importance of social exchanges between employees and its implications for their 
attitudes and behaviors. The perceived coworkers' unfairness could have been viewed as a violation of the organization's obligation to provide workers with a congenial workplace environment that supports teamwork, where members value and respect each other (Kickul \& Liao-troth, 2003) Employees view social relations on the job as not merely a means for achieving assigned tasks but as a way of providing a sense of belonging, affirmation, and support.

Therefore, due to frustration, employees may react to unfair treatment through aggression on coworkers or target of mistreatment. The presence of coworker aggression in the workplace is likely to weaken the cohesiveness among workgroup members with negative implications for employee attitudes, psychological wellbeing and performance (LeBlanc \& Kelloway, 2002). Consequently, the organization's wellbeing may be threatened.

The relationship between employees' job satisfaction and aggressive behavior was not hypothesized in the present study, but an interesting finding emerged that may be due to the suppressor effect of job satisfaction. Job satisfaction was positively related to aggressive behavior, which indicates that satisfied employees are likely to engage in aggressive behavior in our sample. This finding is in contrast with Vigoda (2002), who provided empirical evidence based on a bivariate relationship suggesting that job satisfaction is negatively related to aggressive behavior. The result of this study is counter-intuitive because the conventional thinking is that a dissatisfied employee would be involved in aggressive acts (e.g. Salin, 2003).

The positive relations between satisfaction and aggressive behavior may however have arisen partly because of the low perceived costs and risks of engaging in such behavior by perpetrators in focal organizations. A potential perpetrator is more likely to be deterred from engaging in aggressive behavior if it would attract immediate and stiff reprimand or sanctions which could include dismissal from the organization. Social isolation and punishment by colleagues could also be deterrents.

Anecdotal evidence shows that there is no policy against incivility in focal organizations; therefore, the organization's culture supports the acts. There could be much impetus for employees to engage in the acts either to further personal interests or in retaliation against perceived injustice from colleagues. Second, a weak or laissez faire style of leadership, most especially at the top management level, may have encouraged aggressive behavior by employees when management is seen not to intervene or take actions against acts of incivility in the workplace. Future research should examine the reason(s) and conditions that would motivate a satisfied employee to engage in aggressive behavior in the workplace.

\section{Limitations and Conclusions}

The findings of this study should be interpreted in the light of these limitations. First, all data was collected at a single point in time; therefore, causality cannot be inferred from 
the results. To determine causality, future research investigations might need to collect data at different time points or employ experimental designs.

Also, there are alternative explanations for the observed relationships between variables. For example, it could be that there is a reverse relation between job distress and job satisfaction. This possibility was explored in line with the suggestions of extant literature on stress. The supplementary hierarchical regression results showed that after controlling for the influence of personal factors (age, tenure and sex), job satisfaction explained a significant 9.2 per cent variance $\left(\Delta R^{2}, p<.0001\right)$ in job distress. The sign of the beta weight suggesting the strength of association between job satisfaction and job distress $(\beta=-.31, p<.0001)$ was in the expected direction. By this result, an employee who experiences dissatisfaction due to job demands is likely to develop stress reactions (Chiu \& Kosinski, 1997). Other possible reverse relations are between aggressive behavior, job distress and job satisfaction. The experience of aggressive acts from coworkers or supervisors could result in job distress or dissatisfaction (Aitkinson, 2000; Salin, 2003; Vartia, 2001; Wahl, 2002).

Second, the study employed self-report measures to elicit information from respondents, therefore raising the possibility of mono-method bias. To test for the presence of method variance, Harman one-factor test was performed on the data and results revealed that there was no single general factor that best represented the data (Podsakoff \& Organ, 1986). Therefore, method variance may not be a problem in this study.

Third, the study is based on a single occupation of agricultural extension services. Therefore, it could be argued that the work context of respondents may constrain the results being generalized to universal occupations and jobs. However, it is our contention that the results are of utility because the findings confirmed the results of earlier studies and hypotheses that are firmly grounded in theory.

Finally, the present study considered only the predictive abilities of interactional justice dimensions (SF and CF) against selected criterions to the exclusion of other justice constructs like informational or distributive justice. It could be possible that observed relationships between the justice subscales and criterions would be different if informational or distributive justice had been included in the analysis. This is because of the differential impacts the justice variables have displayed against outcomes in past research and this has prompted the call for examining the effects of multiple types of fairness simultaneously in a single study (Colquitt et al., 2001).

Despite the limitations, the study has made contributions to the existing literature in the following ways: (a) Employees are able to identify sources of unfair treatment in the workplace (i.e. supervisor or coworkers) and these can promote employee dissatisfaction, distress, and aggressive behavior. Therefore, organizations can improve employees' perceptions of interactional fairness through deliberate policies and initiatives that recognize the worth of employees and treat them with respect and dignity. (b) An employee who is stressed on the job is much likely to experience 
dissatisfaction with the job and distress could lead to reactions of aggressive behavior towards the supervisor, coworkers and clients.

\section{References}

Aiken, L. S., \& West, S. G. (1991). Multiple regression: Testing and interpreting interactions. Newbury Park, London: Sage Publications.

Aitkinson, W. (2000). The everyday face of workplace violence: Policies on employee violence and policy coverage (Statistical data included). Risk Management, Retrieved February 5, 2005, from HighBeam Research database.

Apantaku, S. O., Sodiya, C. I., Apantaku, F. S., \& Fakoya, E. O. (2000). Alternative internal sources of funds for extension service in Ogun State, Nigeria. Journal of Sustainable Agriculture, 17(1), 37-54.

Barling, J., \& Phillips, M. (1993). Interactional, formal, and distributive justice in the workplace: An exploratory study. The Journal of Psychology, 127, 649-656.

Becker, T. E., Billings, R. S., Eveleth, D. M., \& Gilbert, N. L. (1996). Foci and bases of employee commitment: Implications for job performance. Academy of Management Journal, 39, 464-482.

Bies, R. J., \& Moag, J. S. (1986). Interactional justice: Communication criteria of Fairness. In R. J. Lewicki, B. H. Sheppard and M. H. Bazerman (Eds.), Research on negotiation in organizations (pp. 43-55). Greenwich, CT: JAI Press.

Bies, R. J., Shapiro, D. L., \& Cummings, L. L. (1988). Causal accounts and managing organizational conflict: Is it enough to say it's not my fault? Communication Research, 15, 381-399.

Boswell, W. R., Olson-Buchanan, J. B., \& LePine, M. A. (2004). Relations between stress and work outcomes: The role of felt challenge, job control, and psychological strain. Journal of Vocational Behavior, 64(1), 165-181.

Brandes, P., Dharwadkar, R., \& Wheatley, K. (2004). Social exchanges within organizations and work outcomes: The importance of local and global relationships. Group and Organization Management, 29(3), 276-301.

Brayfield, A. H., \& Rothe, H. F. (1951). An index of job satisfaction. Journal of Applied Psychology, 35, 307-311.

Bruk-Lee, V., \& Spector, P. E. (2006). The social stressors-counterproductive work behaviors Link: Are conflicts with supervisors and coworkers the same? Journal of Occupational Health Psychology, 11(2), 145-156. 
Cavanaugh, M. A., Boswell, W. R., Roehling, M. V., \& Boudreau, J. W. (2000). An empirical examination of self-reported work stress among U.S. managers. Journal of Applied Psychology, 85, 65-74.

Chen, P. Y., \& Spector, P. E. (1992). Relationships of work stressors with aggression, withdrawal, theft, and substance use: An exploratory study. Journal of Occupational and Organizational Psychology, 65, 177-184.

Chiu, R. K., \& Kosinski, F. A. (1997). Relationships between dispositional traits and self-reported job satisfaction and distress: An investigation of nurses and teachers in Hong Kong. Journal of Managerial Psychology, 12(2), 71-84.

Chukwuone, N. A., \& Agwu, A. E. (2005). Financing agricultural technology delivery in Nigeria: Would farmers be willing to pay? Journal of Extension Systems, 21(2), 69-85.

Cohen-Charash, Y., \& Spector, P. E. (2001). The role of justice in organizations: A meta-analysis. Organizational Behavior and Human Decision Processes, 86(2), 278-321.

Colquitt, J. A., Conlon, D. E., Wesson, M. J., Porter, C.O.L.H., \& Yee Ng, K. (2001). Justice at the millennium: A meta-analytic review of 25 years of organizational justice research. Journal of Applied Psychology, 86, 425-445.

Colquitt, J. A. (2001). On the dimensionality of organizational justice: A construct validation of a measure. Journal of Applied Psychology, 86, 386-400.

Cropanzano, R., Mitchell, M. S. (2005). Social exchange theory: An interdisciplinary review. Journal of Management, 31, 874-900.

Coyle-Shapiro, J. A-M., Kessler, I., \& Purcell, J. (2004). Exploring organizationally directed citizenship behaviors: Reciprocity or "it's my job"? Journal of Management Studies, 41(1), 85-106.

Donovan, M. A., Drasgow, F., \& Munson, L. J. (1998). The perceptions of fair interpersonal treatment scale: Development and validation of a measure of interpersonal treatment in the workplace. Journal of Applied Psychology, 83, 683 $-692$.

Dormann, C., \& Zapf, D. (2002). Social stressors at work, irritation, and depressive symptoms: Accounting for unmeasured third variables in a multi-wave study. Journalof Occupational and Organizational Psychology, 75, 33-58.

Duffy, M. K., \& Ferrier, W. J. (2003). Birds of a feather...? How supervisorsubordinate dissimilarity moderates the influence of supervisor behaviors on workplace attitudes. Group and Organization Management, 28(2), 217-248. 
Etzion, D. (1984). Moderating effect of social support on the stress-burnout relationship. Journal of Applied Psychology, 69, 615-622.

Fortado, B. (2001). The metamorphosis of workplace conflict. Human Relations, 54, $1189-1221$.

Francis, L. (2005). Research forum: Unfairness in the workplace. Retrieved January 3, 2005, from http://www.hrpao.org/HRPAO/Knowledge Centre/

Greenberg, J. (1990). Organizational justice: Yesterday, today, and tomorrow. Journal of Management, 16(2), 399-432.

Greenglass, E. R., Burke, R. J., \& Moore, K. A. (2003). Reactions to increased workload: Effects on professional efficacy of nurses. Applied Psychology: An International Review, 52, 580-597.

Hair, J. F., Anderson, R. E., Tatham, R L., \& Black, W. C. (1992). Multivariate data analysis( $3^{\text {rd }}$ ed.). New York: MacMillan.

Heller, D., Judge, T. A., \& Watson, D. (2002). The confounding role of personality and trait affectivity in the relationship between job and life satisfaction. Journal of Organizational Behavior, 23, 815-835.

Inness, M., Barling, J., \& Turner, N. (2005). Understanding supervisor-targeted aggression: A within-person, between-jobs design. Journal of Applied Psychology, 90, 731-739.

Janssens, M., Sels, L., \& Van den Brande, I. (2003). Multiple types of psychological contracts: A six-cluster solution. Human Relations, 56, 1349-1378.

Kennedy, D. B., Homant, R. J., \& Homant, M. R. (2004). Perception of injustice as a predictor of support for workplace aggression". Journal of Business and Psychology, 18(3), 323- 336.

Kickul, L., \& Liao-Troth, M. A. (2003). The meaning behind the message: Climate perceptions and the psychological contract. Mid-American Journal of Business, 18(2), 23-32.

Kristof-Brown, A. L., Jansen, K. J., \& Colbert, A. E. (2002). A policy-capturing study of the simultaneous effects of fit with jobs, groups, and organizations. Journal of Applied Psychology, 87, 985-993.

Ladebo, O. (2004). Employees' personal motives for engaging in citizenship behavior: The case of workers in Nigeria's agriculture industry. Current Research in Social Psychology, 9(16), 220-233. 
LeBlanc, M. M., \& Kelloway, E. K. (2002). Predictors and outcomes of workplace violence and aggression. Journal of Applied Psychology, 87,444-453.

Mueller, C. W., De Coster, S., \& Estes, S. B. (2001). Sexual harassment in the workplace: Unanticipated consequences of modern social control in organizations. Work and Occupations, 28, 411-446.

Murphy, S. M., Wayne, S. J., Liden, R. C., \& Erdogan, B. (2003). Understanding social loafing: The role of justice perceptions and exchange relationships. Human Relations, 56(1), 61-84.

Namie, G. (2003). Workplace bullying: Escalated incivility. Ivey Business Journal, 68(2), 1-7.

Neuman, J. H., \& Baron, R. A. (1997). Aggression in the workplace. In R. Giacalone \& J. Greenberg (Eds.), Antisocial behavior in organizations (pp. 37-67). Thousand Oaks, CA: Sage.

Noe, R. A., Hollenbeck, J. R., Gerhart, B., \& Wright, P. M. (1994). Human resource management: Gaining a competitive advantage. Burr Ridge, IL: Irwin Inc.

Omotayo, A., Chikwendu, O. K., \& Adebayo, K. (2001). Two decades of World Bank assisted extension services in Nigeria: Lessons and challenges for the future. The Journal of Agricultural Education and Extension, 7(3), 143-152.

Podsakoff, P. M., \& Organ, D. W. (1986). Self reports in organizational leader reward and punishment behavior and research: problems and prospects. Journal of Management, 12, 531-44.

Poon, J. M. L. (2003). Situational antecedents and outcomes of organizational politics Perceptions. Journal of Managerial Psychology, 18, 138-155.

Raabe, B., \& Beehr, T. A. (2003). Formal mentoring versus supervisor and coworker relationships: differences in perceptions and impact. Journal of Organizational Behavior, 24, 271-293.

Reece, B. L., \& Brandt, R. (1999). Effective human relations in organiztions ( $7^{\text {th }}$ ed.). Boston, MA: Houghton Mifflin Co.

Salin, D. (2003). Ways of explaining workplace bullying: A review of enabling, motivating and precipitating structures and processes in the work environment. Human Relations, 56,1213-1232. 
Self, D. R., Holt, D. T., \& Schaninger Jr, W. S. (2005). Work-group and organizational support: A test of distinct dimensions. Journal of Occupational and Organizational Psychology, 78, 133-140.

Smith, T. W., Glazer, K., Ruiz, J. M., \& Gallo, L. C. (2004). Hostility, anger, aggressiveness, and coronary heart disease: An interpersonal perspective on personality, emotion, and health. Journal of Personality, 72,1217-1270.

Spector, P. E., \& Fox, S. (2002). An emotion-centered model of voluntary work behavior: Some parallels between counterproductive work behavior (CWB) and organizational citizenship behavior (OCB). Human Resources Management Review, 12, 269-292.

Tepper, B. J. (2007). Abusive supervision in work organizations: Review, Synthesis, and research agenda. Journal of Management, 33, 261-289.

Tuten, T. L., \& Neidermeyer, P. E. (2004). Performance, satisfaction and turnover in call centers: The effects of stress and optimism. Journal of Business Research, $57,26-34$.

Vandenberghe, C., Bentein, K., \& Stinglhamber, F. (2004). Affective commitment to the organization, supervisor, and workgroup: Antecedents and outcomes. Journal of Vocational Behavior, 64, 47-71.

Vartia, M. A-L. (2001). Consequences of workplace bullying with respect to the well -being of its targets and the observers of bullying. Scandinavian Journal of Work Environment Health, 27(1), 63-69.

Vigoda, E. (2002). Stress-related aftermaths to workplace politics: the relationships among politics, job distress, and aggressive behavior in organizations. Journal of Organizational Behavior, 23, 571-591.

Wahl, K. H. (2002). Addressing issues of workplace harassment: Counseling the targets. Journal of Employment Counseling. Retrieved February 5, 2005, from

HighBeam Research database.

Yoon, J., \& Thye, S. R. (2002). A dual process model of organizational commitment: Job satisfaction and organizational support. Work and Organization, 29, 97-124.

Zdaniuk, B., \& Levine, J. M. (2001). Group loyalty: Impact of members' identification and contributions. Journal of Experimental Social Psychology, 37, 502-509.

Zellars, K. L., Tepper, B. J., \& Duffy, M. K. (2002). Abusive supervision and subordinates' organizational citizenship behavior. Journal of Applied Psychology, 87,1068-1076. 